\title{
МІЖНАРОДНЕ СПІВРОБІТНИЦТВО РАХУНКОВОЇ ПАЛАТИ ЯК ВИЩОГО ОРГАНУ АУДИТУ УКРАЇНИ В МЕЖАХ ЄВРОСАІ
}

Пацкан В. В.

Статтю присвячено проблематиці міжнародного співробітництва Рахункової палати як вищого органу aудиту України в рамках ЄBPOCAI. Визначено основні засади міжнародного співробітництва Рахункової палати як вищого органу аудиту України в рамках ЄBPOCAI. Проаналізовано практику міжнародного співробітництва Рахункової палати як вищого органу аудиту України в рамKax $\in B P O C A I$.

Наголошено, що міжнародне співробітництво Рахункової палати як вищого органу аудиту України у рамках міжнародних організацій також $\epsilon$ важливою гарантією для належного здійснення публічного контролю за надходженням коштів до Державного бюджету України та їх використанням, а також забезпечення прозорості роботи Рахункової палати та доброчесності їі членів і посадових осіб.

Визначено, що існують перспективи подальших наукових досліджень у цьому напрямі, зокрема щодо порівняльно-правового аналізу міжнародного співробітництва Рахункової палати та вищих органів аудиту країн-членів ЄC; міжнародного співробітництва Рахункової палати; адміністративно-правового статусу Рахункової палати.

3'ясовано, що зі збільшенням кількості адміністративних послуг, які надаються органами державної влади в електронному вигляді, зростають і ризики, пов'язані з використанням IT. Віруси, кібератаки, збої у роботі - ось далеко не повний перелік ризиків, які можуть призвести до втрати керованості країною, прийняття неправильних управлінських рішень, невчасного надання послуг населенню.

Зроблено висновок, що міжнародне співробітниитво Рахункової палати як вищого органу аудиту України в рамках ЄBPOCAI має важливе значення для ефективної роботи Рахункової палати як вищого органу аудиту України, забезпечення високого рівня довіри з боку суспільства, інших органів державної влади, міжнародного співтовариства, вищих органів аудиту окремих зарубіжних країн. Важливим у цьому співробітництві $є$ і забезпечення діяльності робочої групи ЄBPOCAl з аудиту коштів, виділених на попередження та ліквідацію наслідків катастроф.

Ключові слова: Рахункова палата, вищий орган аудиту, міжнародне співробітництво, аудит, фінансовий контроль, ЄВРОСАI.

Статья посвящена проблематике международного сотрудничества Счетной палаты как высшего органа аудита Украины в рамках ЕВРОСАИ. Определены основные принципы международного сотрудничества Счетной палаты как высшего органа аудита Украины в рамках ЕBPOСАИ. Проанализирована практика международного сотрудничества Счетной палаты как высшего органа аудита Украины в рамках ЕВРОСАИ.

Отмечено, что международное сотрудничество Счетной палаты как высшего органа аудита Украины в рамках международных организаций также является важной гарантией для надлежащего публичного контроля за поступлением средств в Государственный бюджет Украины и их использованием, а также обеспечения прозрачности работы Счетной палаты и добродетели его членов и должностных лиц.
Определено, что существуют перспективы дальнейших научных исследований в этом направлении, в частности относительно сравнительно-правового анализа международного сотрудничества Счетной палаты и высших органов аудита стран-членов ЕС; международного сотрудничества Счетной палаты; административно-правового статуса Счетной палаты.

Установлено, что с увеличением количества административных услуг, предоставляемыми органами государственной власти в электронном виде, растут и риски, связанные с использованием ИТ. Вирусы, кибератаки, сбои в работе - вот далеко не полный перечень рисков, которые могут привести к потере управляемости страной, принятия неправильных управленческих решений, несвоевременного предоставления услуг населению.

Сделан вывод, что международное сотрудничества Счетной палаты как высшего органа аудита Украины в рамках ЕВРОСАИ имеет важное значение для эффективной работы Счетной палаты как высшего органа аудита Украины, обеспечения высокого уровня доверия со стороны общества, других органов государственной власти, международного сообщества, высших органов аудита отдельных зарубежных стран. Важным в этом сотрудничестве также является обеспечение деятельности рабочей группы ЕВРОСАИ по аудиту средств, выделенных на предупреждение и ликвидацию последствий катастроф.

Ключевые слова: Счетная палата, высший орган аудита, международное сотрудничество, аудит, финансовый контроль, ЕВРОСАИ.

The article is devoted to the problems of the international cooperation of the Accounting Chamber as the supreme audit institution of Ukraine in the framework of EUROSAI. The basic principles of international cooperation of the Accounting Chamber as the supreme audit institution of Ukraine in the framework of EUROSAI are determined. The practice of international cooperation of the Accounting Chamber as the supreme audit institution of Ukraine in the framework of EUROSAl is analysed.

It is emphasized that the international cooperation of the Accounting Chamber as the supreme audit body of Ukraine within the international organizations is also an important guarantee for the proper control over the flow of funds to the State Budget of Ukraine and their use, as well as ensuring the transparency of the work of the Accounting Chamber and the integrity of its members and officials.

It is determined that there are prospects for further scientific research in this area, in particular, regarding: comparative legal analysis of the international cooperation of the Accounting Chamber and the highest audit bodies of the EU Member States; international cooperation of the Accounting Chamber; the administrative and legal status of the Accounting Chamber.

It has been found that with the increasing number of administrative services provided by public authorities in electronic form, the risks associated with the use of IT are increasing. Viruses, cyberattacks, and malfunctions - this is not a complete list of risks that can lead to the loss of control of the country, 
the wrong management decisions, poor delivery of services to the population.

It is concluded that the international cooperation of the Accounting Chamber as the highest audit body of Ukraine within the framework of EUROSAl is essential for the effective operation of the Accounting Chamber as the highest audit body of Ukraine, ensuring a high level of trust on the part of the public, other public authorities, the international community, and the higher audit bodies foreign countries. Also important in this cooperation is the provision of the work of the EUROSAl Working Group on the audit of funds earmarked for disaster prevention and disaster relief.

Key words: Accounting Chamber, Supreme Audit Institution, international cooperation, audit, financial control, EUROSAI.

Постановка проблеми та їі актуальність. У процесі розвитку України як правової і демократичної держави. євроінтеграції України, розвитку Рахункової палати як вищого органу аудиту України, запобігання та протидії корупції в Україні, міжнародного співробітництва України важливого значення набуває дослідження проблематики міжнародного співробітництва Рахункової палати як вищого органу аудиту України в рамках ЄBPOCAI.

Дослідження проблематики міжнародного співробітництва Рахункової палати як вищого органу аудиту України в рамках ЄBPOCAI має важливе практичне значення для подальшого вдосконалення адміністративного законодавства України, міжнародного права, а також для вдосконалення правозастосовної практики в цій сфері. Внаслідок цього дослідження проблематики міжнародного співробітництва Рахункова палата як вищий орган аудиту України в рамках ЄBPOCAI $\epsilon$ важливим для розвитку науки адміністративного права та міжнародного права.

Метою статті $\epsilon$ охарактеризувати проблематику міжнародного співробітництва Рахункової палати як вищого органу аудиту України в рамках ЄBPOCAI.

Завданнями статті $\epsilon$ визначити основні засади міжнародного співробітництва Рахункової палати як вищого органу аудиту України в рамках ЄBPOCAI; проаналізувати практику міжнародного співробітництва Рахункової палати як вищого органу аудиту України в рамках ЄBPOCAI.

Аналіз останніх досліджень і публікацій. Проблематика міжнародного співробітництва Рахункової палати як вищого органу аудиту України в рамках ЄВРОCAI $\epsilon$ актуальною, а окремі іï аспекти були предметом дослідження сучасних науковців, зокрема В. Авер'янова, О. Койчевої, О. Ніконової, Н. Обушної, Ю. Табенської.

Виклад основного матеріалу. Відповідно до ст. 98 Конституції України [1] контроль від імені Верховної Ради України за надходженням коштів до Державного бюджету України та їх використанням здійснює Рахункова палата. Аналіз статусу та повноважень Рахункової палати України свідчить, що вона $\epsilon$ не просто вищим за субординацією, а дійсно провідним органом державного фінансового контролю в Україні, який відповідає міжнародним стандартам, що $є$ важливим, враховуючи курс на євроінтеграцію [2, с. 157]. Отже, Рахункова палата $\epsilon$ вищим органом аудиту в Україні.

Згідно ст. 6 Закону України «Про Рахункову палату» [3] Рахункова палата у порядку, визначеному законодавством і міжнародними договорами України, здійснює співробітництво з вищими органами фінансового контролю інших держав, міжнародними організаціями.
Важливим кроком на шляху до становлення та розвитку Рахункової палати стало їі входження в листопаді 1998 року до Міжнародної організації вищих органів аудиту (далі - IHTOCAI), а у травні 1999 року - до складу Європейської організації вищих органів аудиту (далі ЄBPOCAI). Вступивши в ці міжнародні організації, Рахункова палата стала учасником системи міжнародного обміну професійним досвідом аудиторів всього світу [4].

Рахункова палата $€$ відповідальною за виконання зобов'язань, які випливають із їі членства в ЄBPOCAІ відповідно до Постанови Кабінету Міністрів України «Про порядок участі центральних органів виконавчої влади у діяльності міжнародних організацій, членом яких є Україна» від 13 вересня 2002 року № 1371 [5].

Міжнародна організація вищих органів фінансового контролю (IHTOCAI) $€$ автономною організацією зовнішнього державного фінансового контролю. Це неурядова організація, яка має особливий статус для Економічної і Соціальної Ради (ЕКОСОР) Організації Об'єднаних Націй [6]. Основною метою IHTOCAІ $є$ сприяння обміну ідеями, знаннями і досвідом між членами організації, Вищими органами аудиту (далі - ВОА) всіх країн світу та іншими міжнародними організаціями і зацікавленими сторонами в галузі державного аудиту [7]. Разом із ЄBPOCAI членами IHTOCAI $€$ такі регіональні групи: ASOSAI, ARABOSAI, AFROSAI, CAROSAI, OLACEFS I PASAI [8].

Європейську організацію вищих органів аудиту (ЄBPOCAI) створено у 1990 році з метою забезпечення досягнення цілей INTOSAI на регіональному рівні, надаючи при цьому членам можливість зосередити увагу на притаманних їх регіону питаннях. Натепер ЄВРОCAI об'єднує 50 вищих органів аудиту (49 європейських ВОА і Європейський суд аудиторів). Відповідно до статті 1 Статуту ЄBPOCAІ основна мета організації сприяти розвитку співпраці між національними ВОА, які входять до неї, а також обміну інформацією і документацією, дослідженням у сфері контролю державних фінансів, створенню університетських кафедр державного аудиту та уніфікації термінології у сфері фінансового контролю [9]. Офіційні мови організації - англійська, іспанська, німецька, російська і французька [10].

Президентом ЄBPOCAI призначається на трирічний період керівник організації, яка проводила черговий Конгрес ЄВРОСАІ. Президент проводить засідання Керівного комітету і виступає в ролі зовнішнього представника ЄBPOCAІ. У разі рівного розподілу голосів членів Керівного комітету президент має вирішальний голос [11]. Генеральний секретар $€$ членом Керівної ради ЄBPOCAI і очолює Секретаріат ЄBPOCAI [12].

Керівними органами ЄBPOCAl $\epsilon$ Конгрес, Керівна рада і Секретаріат. Конгрес, який $є$ найвищим органом ЄBPOCAI, скликається раз на три роки. Під час Конгресу розглядаються результати діяльності робочих органів ЄBPOCAI та затверджуються плани роботи на наступні три роки. Згідно зі статтями 5-9 Статуту ЄBPOCAІ Конгрес ЄBPOCAІ у складі керівників ВОФК-членів Організації або їх уповноважених представників $\epsilon$ вищим органом ЄBPOCAІ. Конгреси проводяться кожні три роки. Останній (X) Конгрес ЄBPOCAІ відбувся 22-25 травня 2017 року. Його організатором була Рахункова плата Туреччини. Тема Конгресу: «Впровадження ISSAI: головні завдання та ефективні рішення». Наступний (XI) Конгрес ЄBPOCAІ відбудеться у 2020 році в Чеській Республіці [13]. 
Керівна рада складається з восьми повноправних членів і п'яти спостерігачів. Усі члени Керівної ради $\epsilon$ керівниками вищих органів аудиту європейських країн. Основне завдання Керівної ради полягає у забезпеченні діяльності ЄВРОСАІ відповідно до рішень, які приймаються Конгресом ЄBPOCAІ. У 2008-2014 роках до складу Керівної ради ЄBPOСАІ входила і Рахункова палата. Згідно зі статтями 10-12 Статуту ЄBPOCAІ до Керівної ради Організації входять вісім членів: четверо - в силу займаних ними посад (керівники ВОФК-організаторів двох останніх Конгресів, керівник ВОФК-організатора наступного Конгресу і генеральний секретар ЄBPOCAI), ще четверо виборних членів обираються на 6-річний термін (із переобранням двох членів кожні три роки) [14].

Згідно зі статтями 13-14 Статуту функції постійного Секретаріату ЄBPOCAІ виконує Аудиторський суд Іспанії, на базі якого діє штаб-квартира організації. Секретаріат ЄBPOCAI сприяє контактам і забезпечує зв'язок між членами організації в періоди між конгресами. Секретаріат також відповідає за організацію розгляду пропозицій, які надходять від членів організації і підлягають обговоренню її керівними органами. Секретаріат координує видання Журналу ЄBPOCAІ та обслуговує веб-сайт ЄBPOCAI.

Відповідно до статті 14 Статуту на секретаріат покладаються такі обов'язки:

- готувати засідання Керівного комітету;

- забезпечувати виконання рішень, прийнятих Конгресом і Керівною радою;

- готувати проект бюджету ЄBPOCAI і виносити його на затвердження Керівної ради;

- представляти Керівній раді звітні документи і річний фінансовий звіт ЄBPOCAI;

- виконувати бюджет, вести бухгалтерський облік

та архіви Організації; [15]. виконувати доручення Конгресу і Керівної ради

Робочими органами ЄBPOCAI $€$ Цільові групи:

- цільова група з інституційного розвитку;

- цільова група з професійних стандартів;

- цільова група з обміну знаннями;

- цільова група з управління і зв'язку.

Також $є$ і робочі та спеціальні групи:

- робоча група з інформаційних технологій;

- робоча група з аудиту навколишнього середовища;

- робоча група з аудиту коштів, виділених на попе-

редження та ліквідацію наслідків катастроф;

- робоча група з аудиту муніципалітетів;

- спеціальна група з якості аудиту.

ЄBPOCAI розвиває партнерські відносини з іншими регіональними організаціями вищих органів аудиту, зокрема з OLACEFS, ARABOSAI та ASOSAI.

Рахункова палата в установленому порядку забезпечує участь своїх представників у роботі окремих комітетів, робочих і спеціальних груп, а також навчальних заходах, конференціях, семінарах, організованих під егідою ЄBPOCAI (семінари, програми дистанційного навчання тощо), тематика яких $\epsilon$ актуальною для Рахункової плати. Важливим напрямом співпраці з ЄBPOCAI $€$ головування Рахункової палати в робочій групі ЄВРОCAl з аудиту коштів, виділених на попередження та ліквідацію наслідків катастроф, забезпечення діяльності цієї робочої групи. Також Рахункова палата бере участь і в робочих групах $Є$ BPOCAІ з аудиту:
- навколишнього середовища (ЄBPOCAI WGEA);

- інформаційних технологій (ЄBPOCAI ITWG);

муніципалітетів (ЄBPOCAI TFMA) [16].

Робоча група ЄBPOCAI з аудиту коштів, виділених на попередження та ліквідацію наслідків катастроф, була затверджена в червні 2014 року на IX Конгресі ЄBPOCAI замість існуючої з листопада 2006 року Спеціальної підгрупи ЄBPOCAІ з аудиту коштів, виділених на попередження та ліквідацію наслідків природних, техногенних катастроф і знищення радіоактивних відходів. Ha VII Конгресі ЄBPOCAI у червні 2008 року ця Спеціальна група була трансформована у Спеціальну групу 3 аудиту коштів, виділених на попередження та ліквідацію наслідків катастроф. На IX Конгресі ЄBPOCAI у червні 2014 року Спеціальна група була трансформована у Робочу.

Головою групи є Рахункова палата України. Ї̈̈ Секретаріат знаходиться в Києві. До складу групи входять приблизно 20 членів. Група має за мету здійснення координації і консолідацію зусиль європейських ВОА із забезпечення урядам допомоги у розробці ефективних і результативних засобів, скерованих на попередження і ліквідацію наслідків катастроф [17].

Робоча група з аудиту навколишнього середовища (ЄBPOCAI WGEA) була формально затверджена в 1999 році за рішенням IV Конгресу ЄBPOCAІ у Парижі. Головою групи ЄBPOCAI WGEA $€$ BOA Естонської Республіки, який перейняв це право від ВОА Королівства Норвегія на IX Конгресі ЄBPOCAІ у червні 2014 року. До складу Групи входять 42 члени.

Концепція ЄBPOCAI WGEA співпадає з концепцією INTOSAI WGEA. ЄBPOCAI WGEA та її члени прагнуть того, аби аудит державного сектора став на службу майбутнім поколінням європейців шляхом вдосконалення методів управління природними ресурсами та навколишнього середовища заради здорового шляху життя та процвітання народів Європи. ЄBPOCAI WGEA має на меті розвиток співпраці, заснований на принципах об'єктивності, відкритих контактів і високого професіоналізму. Основні стратегічні цілі групи:

- зміцнення та підтримка професійного співробітництва;

- сприяння обміну знаннями та досвідом [18].

У рамках співробітництва з робочими органами ЄBPOCAI у 2018 році Рахункова палата також брала активну участь у діяльності робочої групи ЄBPOCAI з аудиту навколишнього середовища (ЄBPOCAI WGEA), робочої групи ЄBPOCAІ з інформаційних технологій і спеціальної групи ЄBPOCAI з аудиту муніципалітетів (ЄBPOCAI TFMA). 25-27 квітня 2018 року в рамках діяльності робочої групи ЄBPOCAI WGEA в м. Гельсінкі (Фінляндська Республіка) відбувся практичний семінар із питань управління природоохоронною діяльністю, під час якого представники Рахункової палати ознайомилися з передовим досвідом і методиками ВОФК інших держав і запрошених експертів здійснення аудитів, пов'язаних $з$ управлінням природоохоронною діяльністю, поділилися досвідом проведення Рахунковою палатою аудитів у сфері досягнення цілей сталого розвитку, а також ознайомили присутніх із діяльністю робочої групи ЄBPOCAІ з аудиту коштів, виділених на попередження та ліквідацію наслідків катастроф.

Делегація Рахункової палати взяла участь у XVI щорічному засіданні робочої групи ЄBPOCAI WGEA 
та тематичному практичному семінарі «Зміна клімату: фокус на даних», які відбулися 25-28 вересня 2018 року в м. Братислава (Словацька Республіка). На засіданні обговорювалися питання політики зміни клімату: аудити ВОФК щодо змін клімату, вплив аудитів навколишнього середовища, краща практика та досвід ВОФК у підвищенні впливу аудиту. Представники Рахункової палати виступили з доповіддю на тему: «Аудити навколишнього середовища: практика проведення та оцінка результатів», яка викликала зацікавленість у представників різних ВОФК.

Делегація Рахункової палати також взяла участь у попередньому засіданні Наглядової ради ЄBPOCAI WGEA, на якому обговорювалося питання подальшої діяльності робочої групи, зокрема співпраці з Форумом Європейської комісії з питань дотримання природоохоронного законодавства та управління. Більшістю учасників було підтримано рішення щодо участі ЄBPOCAI WGEA як спостерігача у форумі [19].

Робоча група з інформаційних технологій (ЄBPOCAI ITWG) була створена в 2002 році на V Конгресі $€$ BPOCAI у Москві. Головою групи ЄBPOCAI ITWG $€$ BOA Республіки Польща, який перейняв це право від ВОА Швейцарії на IX Конгресі ЄBPOCAІ у червні 2014 року. До складу групи входять більше 30 членів. Група ЄBPOCAI ITWG має за мету розширення інституційного обміну досвідом і знаннями між ВОА європейського регіону та сприяння проведенню спільних контрольних заходів у сфері інформаційних технологій. Робоча група прагне доповнювати ініціативи Постійного комітету INTOSAI інформаційними технологіями та сприяти обміну досвідом між обома організаціями [20].

Зі збільшенням кількості адміністративних послуг, які надаються органами державної влади в електронному вигляді, зростають і ризики, пов'язані з використанням IT. Віруси, кібератаки, збої у роботі - ось далеко не повний перелік ризиків, які можуть призвести до втрати керованості країною, прийняття неправильних управлінських рішень, невчасного надання послуг населенню. Про це заявив член Рахункової палати Ігор Яремчук під час виступу на 13 засіданні робочої групи ЄBPOCAI з інформаційних технологій у Флоріані (Мальта). Доповідь була присвячена обґрунтованості здійснення державного зовнішнього аудиту інформаційних технологій державних органів України.

Член Рахункової палати наголосив, що зі збільшенням електронних державних послуг зростають і ризики, пов'язані з використанням IT. «Наведу лише один приклад: за оцінками фахівціввтрати від розповсюдження вірусу Petya у 2017 році становили 0,4\% ВВП України. І це тільки матеріальні втрати, - зазначив Ігор Яремчук. Перший крок для запобігання кібератакам - незалежне та неупереджене встановлення фактичного стану автоматизованих інформаційних систем органів державної влади і надання оцінки їх результативності та ефективності, тобто проведення незалежного зовнішнього аудиту IT-систем».

В Україні працює низка аудиторських компаній, які пропонують проведення IT-аудиту, а також їхніх філій, які забезпечують проведення IT-аудиту на підприємствах та у фінансових установах (PwC, Deloitte, BDO тощо). Водночас законодавством не передбачено проведення IT-аудиту в органах влади, але деякі державні установи усвідомлюють важливість інформаційних технологій у їх діяльності і необхідність зовнішньої оцінки ІT-інфраструктури. Наприклад, у лютому 2019 року командою фахівців Deloitte і Мінфіну було проведено IT-аудит інформаційних систем Державної фіскальної служби України, у 2013-2014 роках - міжнародний координований паралельний аудит інформаційних систем управління державним боргом відповідно до Стратегічного плану робочої групи INTOSAI із державного боргу (WGPD) [21].

Спеціальна група ЄBPOCAI 3 аудиту муніципалітетів (ЄBPOCAI TFMA) була створена в червні 2016 року за рішенням, прийнятим на 44-му засіданні Керівного комітету ЄBPOCAI. Головою ЄBPOCAI TFMA $€$ Національний аудиторський офіс Литовської Республіки спільно з Секретаріатом, розташованим у Вільнюсі. До складу Групи входять 28 членів. Метою ЄBPOCAI TFMA $\epsilon$ створення відкритої платформи з обміну найкращою практикою та досвідом у сфері аудиту муніципалітетів.

Діяльність ЄBPOCAI TFMA здійснюється в рамках стратегічної цілі ЄBPOCAІ з розвитку професійного співробітництва й базується на трьох стратегічних цілях групи:

1. Обмін найкращими практиками та корисним досвідом для досягнення результативності аудиту, які мають суттєвий вплив на покращення управління державними фінансами.

2. Підвищення ефективності системи зовнішнього аудиту муніципалітетів.

3. Сприяння проведенню спільних міжнародних аудитів [22].

Важливим заходом у рамках співпраці з ЄBPOCAI стала участь Рахункової палати у II засіданні спеціальної групи ЄBPOCAI з аудиту муніципалітетів (ЄBPOCAI TFMA) та семінарі «Фінанси органів місцевого самоврядування: виклики майбутнього», які відбулися 4-7 листопада 2018 року в м. Белград (Республіка Сербія).

У зазначених заходах взяли участь представники 29 вищих органів фінансового контролю країн-членів ЄBPOCAI та запрошені гості. Під час семінару обговорювалися актуальні питання формування та аналізу державної політики у сфері місцевих фінансів, роль і ключові функції органів центральної влади в системі управління місцевими фінансами, законодавче регулювання систем управління фінансами місцевих бюджетів. Розглядалися також практичні аспекти діяльності ВОФК, зокрема процедури постконтролю за виконанням рекомендацій, наданих за результатами аудитів місцевих бюджетів [19].

У рамках співробітництва з ЄBPOCAI у 2018 році Рахункова палата продовжувала брати активну участь у діяльності робочих органів цієї міжнародної організації. Зокрема, делегація Рахункової палати 14-15 березня 2018 року взяла участь у 49 засіданні Керівної ради ЄBPOCAI, яке відбулося в м. Гданськ (Республіка Польща). Під час засідання учасники розглянули важливі питання діяльності організації: звіт про діяльність ЄBPOCAI за 2017-2018 роки; стан упровадження Стратегічного плану ЄBPOCAI на 2017-2023 роки; Оперативний план заходів ЄBPOCAІ щодо модернізації ВОФК і надання допомоги у вирішенні нових завдань, заслухали звіти голів робочих і спеціальних груп ЄBPOCAI.

Рахункова палата представила звіт про діяльність робочої групи ЄBPOCAІ з аудиту коштів, виділених на попередження та ліквідацію наслідків катастроф, із червня 2017 по березень 2018 року та ознайомила учасників засідання з перспективами на майбутнє. Крім 
того, в рамках засідання представники ВОФК України, Республіки Польща та Словацької Республіки підписали Спільний звіт про результати Міжнародного координованого аудиту функціонування Міжнародного біосферного заповідника «Східні Карпати», головна мета якого - оцінка ефективності функціонування об'єктів природно-заповідного фонду в межах міжнародного резервату, а також надання рекомендацій щодо покращення наявного стану.

У 2018 році одним із пріоритетних завдань міжнародного співробітництва було забезпечення діяльності очолюваної Рахунковою палатою робочої групи EBPOCAI з аудиту коштів, виділених на попередження та ліквідацію наслідків катастроф, до складу якої входять 17 постійних членів та два спостерігачі. Згідно зі Стратегією та планом діяльності робочої групи на 2017-2020 роки місія робочої групи полягає у підвищенні потенціалу, об'єднанні і координації зусиль європейських ВОФК у сприянні національним урядам у виробленні діючих ефективних інструментів попередження та ліквідації наслідків катастроф.

Для реалізації зазначених цілей 29-30 березня 2018 року в м. Кишинів (Республіка Молдова) під головуванням Рахункової палати України та за підтримки Рахункової палати Республіки Молдова відбулося IV засідання робочої групи ЄBPOCAI з аудиту коштів, виділених на попередження та ліквідацію наслідків катастроф, в якому взяли участь представники 10 ВОФК країн Європи [19].

Висновки. Отже, міжнародне співробітництва Рахункової палати як вищого органу аудиту України в рамках ЄBPOCAI має важливе значення для ефективної роботи Рахункової палати як вищого органу аудиту України, забезпечення високого рівня довіри з боку суспільства, інших органів державної влади, міжнародного співтовариства, вищих органів аудиту окремих зарубіжних країн. Важливим у цьому співробітництві також $є$ забезпечення діяльності робочої групи ЄBPOCAI з аудиту коштів, виділених на попередження та ліквідацію наслідків катастроф.

Доцільно уточнити і гармонізувати фахову термінологію чинного Закону України «Про Рахункову палату» та інших нормативно-правових актів законодавства України із провідними документами ЄBPOCAІ у зв'язку з численними розбіжностями щодо розуміння окремих фахових термінів у документах ЄBPOCAІ та у відповідних нормативно-правових актах профільного законодавства України з питань Рахункової палати як вищого органу аудиту, їх перекладу українською мовою. Міжнародне співробітництво Рахункової палати як вищого органу аудиту України в рамках міжнародних організацій також $\epsilon$ важливою гарантією для належного здійснення публічного контролю за надходженням коштів до Державного бюджету України та їх використанням, забезпечення прозорості роботи Рахункової палати та доброчесності їі членів і посадових осіб.

Перспективи подальших наукових досліджень у цьому напрямі стосуються порівняльно-правового аналізу міжнародного співробітництва Рахункової палати та вищих органів аудиту країн-членів $Є C$; міжнародного співробітництва Рахункової палати; адміністративно-правового статусу Рахункової палати. Загалом у статті охарактеризовано проблематику міжнародного співробітництва Рахункової палати як вищого органу аудиту України в рамках ЄBPOCAI.

\section{Література}

1. Конституція України від 28 червня 1996 року. Відомості Верховної Ради України. 1996. № 30. Ст. 141.

2. Койчева О.С. Конституційний статус рахункової палати України в системі органів державного фінансового контролю. Право і суспільство. 2014. № 6.1. С. 151-158.

3. Про Рахункову палату : Закон України від 2 липня 2015 року. Відомості Верховної Ради України. 2015. № 36. СТ. 360 .

4. Рахункова палата України. URL: www.ac-rada.gov. ua/1.html (дата звернення: 20 жовтня 2019 року).

5. Про порядок участі центральних органів виконавчої влади у діяльності міжнародних організацій, членом яких $є$ Україна : Постанова Кабінету Міністрів України від 13 вересня 2002 року № 1371. Офіційний вісник України. 2002. № 38. Ст. 1776.

6. ИНТОСАИ - Международная организация высших органов аудита. URL: https://www.intosai.org/ru/ (дата звернення: 21 жовтня 2019 року).

7. O нашей работе. URL: https://www.intosai.org/ru/ o-nashei-rabote/ (дата звернення: 21 жовтня 2019 року).

8. O EUROSAI. URL: https://www.eurosai.org/ru/aboutus/about-eurosai/ (дата звернення: 21 жовтня 2019 року).

9. Цели EUROSAI. URL: https://www.eurosai.org/ru/ about-us/about-eurosai/the-objectives-of-eurosai/ (дата звернення: 21 жовтня 2019 року).

10. Рабочие языки EUROSAI. URL: https: / / www.eurosai.org/ru/about-us/about-eurosai / eurosai-languages/ (дата звернення: 21 жовтня 2019 року).

11. Президент. URL: https://www.eurosai.org/ru/ about-us/president/ (дата звернення: 21 жовтня 2019 року).

12. Генеральный секретарь. URL: https: / / www.eurosai.org/ru/about-us/secretary-general / (дата звернення: 22 жовтня 2019 року).

13. Конгресc. URL: https://www.eurosai.org/ru/aboutus/congress/ (дата звернення: 22 жовтня 2019 року).

14. Руководящий комитет. URL: https: / / www.eurosai.org/ru/about-us/governing-board/ (дата звернення: 22 жовтня 2019 року).

15. Секретариат. URL: https://www.eurosai.org/ru/ about-us/secretariat/ (дата звернення: 22 жовтня 2019 року).

16. Співпраця Рахункової палати з EUROSAI. URL: https://rp.gov.ua/EUROS/EUROSAl/?id=117 (дата звернення: 22 жовтня 2019 року).

17. Робоча група EUROSAI з аудиту коштів, виділених на попередження та ліквідацію наслідків катастроф. URL: https://rp.gov.ua/EUROS/FADC/?id=127 (дата звернення: 15 вересня 2019 року).

18. Робоча група з аудиту навколишнього середовища. URL: https://rp.gov.ua/EUROS/WGEA/?id=105 (дата звернення: 23 жовтня 2019 року).

19. Звіт Рахункової палати за 2018 рік. URL: https://rp.gov.ua/upload-files/Activity/Reports/2018/ZVIT_ RP_2018.pdf (дата звернення: 23 жовтня 2019 року).

20. Робоча група з інформаційних технологій. URL: https://rp.gov.ua/EUROS/ITWG/?id=126 (дата звернення: 23 жовтня 2019 року).

21. Рахункова палата продовжує професійне співробітництво з європейськими ВOA у сфері IT. URL: https: //rp.gov.ua/IntCooperation/Events/?id=94 (дата звернення: 23 жовтня 2019 року).

22. Спеціальна група з аудиту муніципалітетів (TFMA). URL: https://rp.gov.ua/EUROS/TFMA/?id=128 (дата звернення: 23 жовтня 2019 року).

Пацкан В. В., здобувач кафедри адміністративного, фінансового, інформаційного права ДВНЗ «Ужгородський національний університет» 